\title{
PENGARUH PENERAPAN METODE BERMAIN TERHADAP PENGUASAAN TEKNIK DASAR LOMPAT JAUH SISWA KELAS VI SDN 2 PANUNGGUL KECAMATAN GEGESIK KABUPATEN CIREBON
}

\author{
Endi Rustandi ${ }^{1}$ dan Toto Sukriyanto ${ }^{2}$ \\ Universitas Majalengka, Indonesia \\ endirustandi@unma.ac.id
}

\begin{abstract}
ABSTRAK. Penelitian ini dilakukan untuk mengetahui pengaruh penerapan metode bermain terhadap penguasaan teknik dasar lompat jauh di sdn 2 panunggul kecamatan gegesik kabupaten cirebon. Dengan tujuan penerapan metode bermain dalam penelitian ini dapat digunakan menjadi salah satu pembelajaran yang efektif, kreatif dan berpengaruh positif terhadap menurunya tingkat kejenuhan siswa. Jenis penelitian ini menggunakan desain eksperimen (eksperimen) dengan menggunakan sampel berjumlah 25 sampel (total sampling) dan dari 25 sampel tersebut yaitu siswa kelas VI dan kemudian dilakukan treatment selama 13 kali pertemuan. Instrumen dalam penelitian ini adalah menggunakan pretest-post test dengan skala pengukuran dengan teknik pengolahan data menggunakan uji normalitas dan uji paired sample T tes. Hasil penelitian ini menunjukan bahwa berpengaruh terhadap penerapan metode bermain terhadap penguasaaan teknik dasar lompat jauh. Karena nilai $\mathrm{T}=-6.263$ hasil penelitian membuktikan bahwa metode bermain memiliki pengaruh yang positif dan signifikan terhadap penguasaan teknik dasar lompat jauh.
\end{abstract}

Kata Kunci: Metode Bermain; Lompat Jauh

\section{Pendahuluan}

Pendidikan jasmani olahraga dan kesehatan adalah suatu proses pembelajaran melalui aktivitas jasmani yang didesain untuk meningkatkan kesegaran jasmani, mengembangkan keterampilan motorik, pengetahuan dan perilaku hidup sehat dan aktif, sikap sportif dan kecerdasan emosi (Depdiknas: 2004). Olahraga atletik termasuk dalam mata pelajaran pendidikan jasmani olahraga dan kesehatan dan merupakan salah satu mata pelajaran yang wajib diajarkan pada siswa di Sekolah Dasar (SD) sesuai dengan materi kurikulum tingkat satuan pendidikan. (KTSP) standar kompetensi Sekolah Dasar.

Lompat jauh adalah kemampuan gerak berpindah dari satu tempat ke tempat lainnya dengan satu kali tolakan ke depan sejauh mungkin. Untuk memperoleh hasil yang maksimal, pelompat dapat melakukannya dengan berbagai gaya. Adanya beberapa gaya yang terdapat dalam lompat jauh, yakni: (1) gaya jongkok (gaya tuck), (2) gaya berjalan di udara (walking in the air), dan (3) gaya menggantung (gaya hang).

Kemampuan melakukan teknik lompat jauh gaya jongkok merupakan salah satu teknik yang harus dikuasai oleh peserta didik dalam mata pelajaran pendidikan jasmani olahraga dan kesehatan pokok bahasan atletik. pendidikan sebagai suatu proses pembinaan 
manusia yang berlangsung seumur hidup, pendidikan jasmani, olahraga dan kesehatan yang diajarkan disekolah memiliki peranan sangat penting, yaitu memberikan kesempatan kepada peserta didik untuk terlibat langsung dalam berbagai pengalaman belajar melalui aktivitas jasmani, olahraga dan kesehatan yang terpilih yang dilakukan secara sistematis. Pembekalan pengalaman belajar itu diarahkan untuk membina pertumbuhan fisik dan pengembangan psikis yang lebih baik, sekaligus membentuk pola hidup sehat dan bugar sepanjang hayat. Pendidikan jasmani, olahraga, dan kesehatan merupakan media untuk mendorong pertumbuhan fisik, perkembangan psikis, keterampilan motorik, pengetahuan dan penalaran, penghayatan nilainilai (sikap-mental emosional-sportivitas-spiritual-sosial), serta pembiasaan pola hidup sehat yang bermuara untuk merangsang pertumbuhan dan perkembangan kualitas fisik dan psikis yang seimbang.

Bagi siswa pemula sering kali kekurangan yang dimiliki yaitu pemahaman teknik dasar lompat jauh yang kurang baik .dan pada dasarnya pemahaman yang kurang baik menyebabkan teknik awalan, tumpuan, saat melayang dan mendarat kurang baik, sehingga lompat jauh yang dicapai kurang optimal. Keadaan tersebut perlu upaya pemecahan. Salah satu upaya pemecahan yang dapat dilakukan yaitu, dengan memberikan pelajaran yang bertujuan untuk memperbaiki teknik lompat jauh yang lebih baik. Ada beberapa faktor penyebab sehingga terjadi hal yang demikian diantaranya adalah pada umumnya di Sekolah Dasar sarana khususnya lompat jauh sangat terbatas jumlahnya yang tidak sesuai dengan jumlah siswa yang akan mengunakannya dan dengan kurangnya media inilah juga yang menyulitkan Guru mentransfer ilmu kepada siswanya sehingga proses pembelajaran menjadi tidak maksimal.

Berdasarkan fakta yang dikemukakan tersebut dan untuk menyesesuaikan dengan tingkat kemampuan fisik siswa maka dalam penelitian ini penulis berusaha mengembangkan metode bermain yang dapat diaplikasikan siswa dengan cara memodifikasi pembelajaran lompat jauh agar siswa dapat melaksanakan pembelajaran materi lompat jauh dengan bersemangat, aktif, dan menyenangkan, Kemudian siswa memperoleh kepuasan dalam mengikuti pelajaran. Selanjutnya meningkatkan kemungkinan keberhasilan siswa dalam berpartisipasi, Siswa dapat melakukan pola gerak dasar dengan benar.

Karena dirasa metode bermain ini sangatlah menarik untuk diteliti. Sehingga peneliti merasa dengan ini akan dapat lebih efisien dalam "Pengaruh penerapan metode bermain terhadap penguasaan teknik dasar lompat jauh di SDN 2 Panunggul“". Maka dengan melalui penerapan metode bermain tersebut akan memberikan kesempatan siswa untuk mengoreksi kesalahan yang telah dilakukan dalam melakukan lompat jauh. 
Menurut Hendrayana (2014) Prinsip dasar lompat jauh adalah "membangun awalan yang secepat-cepatnya dan melakukan tolakan yang sekuat- kuatnya kearah depan atas dengan satu kaki untuk meraih ketinggian yang optimal saat melayang sehingga menghasilkan jarak lompatan yang sejauh-jauhnya". Sedangkan menurut Menurut Wiarto (2013) Beberapa tujuan umum dalam pembelajaran cabang lompat jauh antara lain sebagai berikut:

1. Awalan adalah gerakan pemulaan dalam usaha untuk mendpatkan kecepatan yang setinggi-tingginya pada waktu akan melakukan tolakan.

2. Tolakan adalah perubahan perpindahan gerakan dari gerakan horizontal ke gerakan vertical yang dilakukan secara cepat.

3. Sikap melayang di udara adalah sikap kaki tolak menolakkan kaki pada balok tumpuan.

4. Mendarat adalah sikap terakhir dari rangkaian gerakan lompa jauh dan merupakan teknik terakhir dari 4 teknik dasar dalam lompat jauh.

Istilah bermain menurut etimologis tergolong kata kerja, sedangkan permainan merupakan kata benda. Anak bermain berarti anak mengerjakan sesuatu permainan, sedang permainan merupakan sesuatu yang dikenai dalam bermain. Menurut Hurlock (1978) dalam Fadlillah (2017) mengategorikan bermain menjadi dua yaitu, bermain aktif dan bermain pasif. Bermain aktif adalah kegiatan bermain dimana kesenangan timbul dari apa yang dilakukan individu. Adapun bermain pasif yaitu, kegiatan bermain dimana kesenangan diperoleh dari kegiatan orang lain.

Dalam penelitian ini dilatar belakangi dari hasil pengamatan penulis dengan materi lompat jauh pada siswa di SDN 2 Panunggul yang kurangnya pencapaian lompat jauh dari mulai sikap awalan, tolakan, saat melayang di udara dan saat mendarat masih kurang baik. Untuk memperbaiki kurangnya pencapaian lompat jauh tersebut guru, melakukan perbaikan dengan mengganti metode yang berbeda dari sebelumnya. Metode yang dipilih adalah metode yang disesuaikan dengan karakteristik anak yaitu bermain.

\section{Metode Penelitian}

Menurut Sugiyono (2011) dengan cara ini peneliti sengaja membangkitkan timbulnya suatu kejadian atau keadaan, kemudian diteliti bagaimana akibatnya. Dengan kata lain, eksperimen adalah suatu cara untuk mencari hubungan sebab akibat (hubungan kausal) antara dua faktor yang sengaja ditimbulkan oleh peneliti dengan mengeliminasi atau mengurangi atau menyisihkan faktor-faktor yangmengganggu. Eksperimen selalu dilakukan dengan maksud untuk melihat akibat suatu perlakuan. 
Subjek penelitian ini adalah seluruh siswa kelas VI yang berjumlah 25 siswa di SDN Negeri 2 Panunggul Kecamatan Gegesik Kabupaten Cirebon. Waktu pelaksanaan pre test pada hari Sabtu, 03 Agustus 2019 pukul 07.30-09.00 WIB sedangkan untuk post test pada hari Sabtu, 14 September 2019 pukul 07.30-09.00. Penerapan dilaksanakan sebanyak 12 kali pertemuan, dengan frekuensi 2 kali dalam satu minggu. Penelitian ini merupakan penelitian eksperimen. Data pada penelitian ini terdiri dari hasil tes lompat jauh.

a. Data Proses

Data proses merupakan data yang mengenai tentang hasil-hasil observasi selama kegiatan pembelajaran berlangsung. Data proses meliputi kinerja guru dan semua aktivitas siswa

b. Data Hasil

Teknik pengolahan data tes hasil belajar yang digunakan peneliti yaitu berupa penilaian ketrampilan proses yang terjadi dari empat aspek, yaitu : Menurut M. Barrow (dalam: freeman, 2001). Yang dikutip oleh Abduljabar (2013)

1. Langkah Lari Awalan

Awalan lari lompat jauh dilakukan dalam garis lurus dengan lari pelan semakin dipercepat, kecepatan dipertahankan sampai menjelang bertolak.

2. Teknik Tolakan

Tolakan kaki tumpu menggunakan kaki yang terkuat dan kaki yang digunakan harus tepat pada papan tumpu agar menghasilkan gerakan maksimal.

3. Teknik Melayang

Pada saat ketinggian maksimal sikap badan dan kaki jongkok, setelah bergerak turun kedua kaki diluruskan ke depan.

4. Teknik mendarat

Saat gerakan mendarat dilakukan dengan kedua kaki secara bersamaan sejajar dan lutut segera ditekuk, kedua tangan ke depan dan badan condong ke depan.

\section{Hasil Penelitian}

Penelitian ini merupakan penelitian eksperimen dengan menggunakan model pre-test post-test design. Subjek dalam penelitian ini ialah siswa kelas VI SD Negeri 2 Panunggul namun dalam teknik pengambilan sampel dalam penelitian ini menggunakan teknik sampel jenuh yang artinya pengambilan data dengan total jumlah siswa dipertimbangkan kembali untuk memilih hanya satu kelas yang menjadi sampel. Oleh karena itu, sampel yang digunakan dalam penelitian ini sebanyak 25 siswa. 
Teknik pengumpulan data dalam penelitian ini adalah menggunakan tes. Setelah data penelitian terkumpul dilakukan analisis menggunakan analisis pre- test and post-test dengan bantuan SPSS.

Hasil analisis statistic deskriptif pretest, di dapat nilai minimal $=20$, nilai maksimal $=$ 80 , rata-rata $=56,8$. Sedangkan post test di dapat nilai minimal $=30$, nilai maksimal $=90$, ratarata $=67.6$, Hasil sebagai berikut:

Tabel 4.1

Deskripstif Statistik Pretest dan Post test penguasaan teknik dasar lompat jauh

\begin{tabular}{|l|l|l|}
\hline Statistik & Pretest & Posttest \\
\hline Jumlah Skor & 1420 & 1690 \\
\hline Rata - Rata & 56,8 & 67,6 \\
\hline Minimum & 20 & 30 \\
\hline Maximum & 80 & 90 \\
\hline
\end{tabular}

\section{Pengujian Normalitas}

Tujuan dari normalitas data adalah untuk mengetahui apakah data yang diperoleh dari hasil test sebenarnya mengikuti pola sebaran normal atau tidak. Uji normalitas data dalam penelitian ini menggunakan uji Shapiro-Wilk.

Berdasarkan tabel di atas terlihat bahwa dengan mengambil taraf signifikansi $\alpha$ sebesar 5\% maka kriteria pengujian yang dilakukan sebagai berikut. Jika Sig. > 0,05 maka berdistribusi normal.

Jika Sig. 0,05 maka tidak berdistribusi normal

Artinya bahwa kedua data tersebut $>0,05$ maka berdistribusi dari populasi yang menyebar adalah normal. Dengan demikian, uji-t dapat diterapkan.

Tabel 4.2

Hasil Perhitungan Uji Normalitas Data Pre Test dan Post Test Penguasaan Teknik Dasar Lompat Jauh

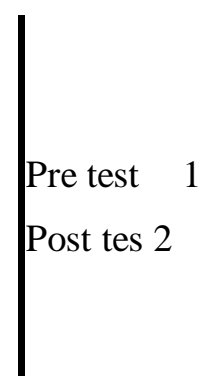

\begin{tabular}{|l|l|l|l|r|r|} 
Kolmogorov-Smirnov & \multicolumn{2}{|l|}{ Shapiro-Wilk } \\
Statistic & Df & Sig. & Statistic & df & Sig. \\
.217 & 25 & .004 & .911 & 25 & .032 \\
.245 & 25 & .000 & .904 & 25 & .023
\end{tabular}

Untuk mengetahui ada atau tidak adanya pengaruh signifikansi dari perlakuan serta untuk mengetahui ada atau tidak adanya perbedaan keefektifan metode problem solving, maka dilakukan perhitungan dengan bantuan software Statistical Product and Service Solution (SPSS) Statistics 16.0 diperoleh uji Paired Sample T test sebagai berikut: 
Tabel 4.3

Paired Samples T Test

\begin{tabular}{|l|l} 
& \\
Pair 1 tes awal & - \\
- tes akhir & 1.080 \\
& $00 \mathrm{E} 1$
\end{tabular}

Paired Differences

Std.

Deviatio $n$

8.62168
95\% Confidence

Interval of the

Difference

Std. Error

Mean

1.72434

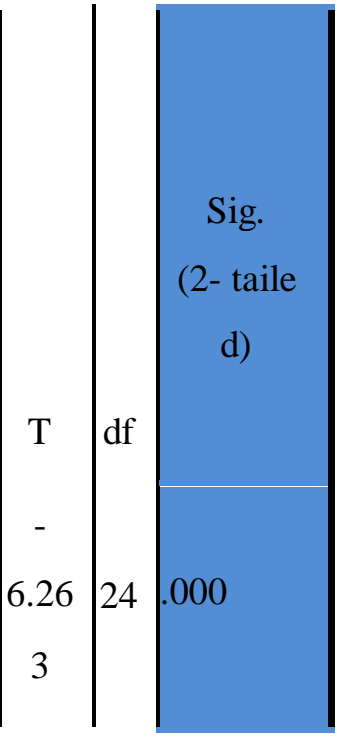

\section{Pembahasan Hasil Penelitian}

Berdasarkan hasil temuan penelitian yang dilakukan peneliti dengan menggunakan metode bermain terhadap penguasaan teknik dasar lompat jauh, maka berikut pembahasan hasil penelitian.

Metode bermain terhadap penguasaan teknik dasar lompat jauh pada penelitian ini bertujuan untuk mengetahui apakah terdapat pengaruh pada penguasaan teknik dasar lompat jauh. Berdasarkan analisis hasil penelitian penguasaan teknik dasar lompat jauh pada metode bermain, dapat disimpulkan pada hasil pre test dan post test pada penguasaan teknik dasar lompat jauh memperoleh nilai rata-rata meningkat, hal ini menunjukkan bahwa metode bermain diterima oleh peserta dengan baik artinya peserta mengikuti dengan baik metode bermain. Karena, pada metode latihan ini terdiri dari empat jenis permainan yaitu: (1) Lari bolak-balik mengambil bola (shuttle run), (2) Melewati ban bekas, (3) Meraih bola yang digantung, (4) Melewati kardus, dari beberapa jenis permainan tersebut menimbulkan motivasi anak untuk mengikuti pembelajaran sehingga tingkat kemauan peserta untuk melakukan pembelajarannya lebih tinggi. Ada salah satu tahapan yang mampu membuat anak merasa terdorong untuk meningkatkan penguasaan teknik dasar lompat jauh adalah pada saat peserta diberikan jenis-jenis permainan dari metode bermain yang bervariatif dengan bantuan alat bantu serta multimedia yang menarik. Karena kalau tidak anak tidak mendapatkan motivasi tambahan dalam latihan. ada salah satu tahapan dimana banyak menyita waktu sehingga keterbatasan waktu dalam proses latihan berlangsung. 
Aktivitas peserta pada metode bermain berjalan dengan yang diharapkan, artinya peserta merasa senang dan merasa lebih bertanggung jawab pada pembelajaran yang diberikan, peserta saling berinteraksi dengan teman-temannya sehingga mampu mengikuti metode bermain yang diberikan. Dengan demikian, tingkat penguasaan teknik dasar lompat jauh dapat meningkat dengan baik.

\section{Kesimpulan}

Data hasil penguasaan teknik dasar lompat jauh pretest mendapatkan nilai minimal 20, nilai maksimal 80, rata-rata 56,8, Hal ini disebabkan oleh kurangnya variansi metode bermain dalam pembelajaran sehingga membuat kondisi ini siswa kurangnya semangat dalam melakukan pembelajaran. Setelah melaksanakan pembelajaran dengan menggunakan metode bermain post test didapat nilai minimal 30, nilai maksimal 90, rata-rata 67,6, sehingga siswa lebih termotivasi ketika proses pembelajaran teknik dasar lompat jauh sehingga dapat meningkatkan hasil penguasaan yang telah tercapai.

\section{Daftar Pustaka}

Bermsalmon, A. (2016). "Efektifitas Penggunaan Metode Bermain di Paud Nazareth Oesapa". Jurnal Pendidikan Anak.

Utami, M. (2016). "Pengembangan Kreativitas Anak Usia Dini Melalui Metode Bermain dengan Permainan Balok di Taman Kanak-Kanak Sabrina Sukarame Bnadra Lampung". Jurnal Pendidikan Anak

Sunarto. (2015). "Peningkatan Pembelajaran Lompat Jauh dengan Metode Bermain Kelas V Sekolah Dasar Siyono 1 Playen Gunung Kidul". Jurnal Pendidikan Olahraga

Hendrayana, R. (2014). "Bermain Atletik". Universitas Pendidikan Indonesia

Giri, W. (2013). “Atletik”. Yogyakarta: Graha Ilmu

Fadillah. (2017). "Bermain dan Permainan Anak Usia Dini”. Jakarta: Kencana.

Husdarta, S. (2014). "Belajar dan Pembelajaran Pendidikan Jasmani dan Kesehatan". Bandung: Alfabeta

Juliantine, T., dkk, (2012). "Belajar dan Pembelajaran Penjas". Universitas Pendidikan Indonesia

Sugiyono. (2011). "Metode Penelitian Pendidikan Pendekatan Kuantitatif, kualitatif dan R\&D". Bandung: Alfabeta.

https//idtesis.com/metode pembelajaran-permainan 